\title{
FEATURES OF PRACTICAL STUDENTS' TRAINING IN OLEXIY HRYHOROVYCH MOROZ'S SCIENTIFIC AND PEDAGOGICAL RESEARCH
}

The article deals with the scientific and pedagogical heritage of Moroz Oleksiy Hrygorovych, the issue of the importance of out-ofclass modern students' work, the concepts and content of their individual work, pedagogical conditions of ensuring the individual educational activity of students of third level educational institutions. The article analyzes Oleksiy's Hrygorovych Moroz scientific and pedagogical heritage. It emphasizes the importance of effective organization and pedagogical conditions for providing individual student's work. It is concluded, that:

- in conditions of students' creative cognitive activity intensification during the educational process individual work can not only be reduced to the implementation of normative home assignment;

- students' independence and creative activity are to be started not in the audience when listening to and acquiring lectures but when preparing for them in the laboratory, library, during practice in school etc. According to O.H. Moroz, this activity, with the transfer of students to senior courses, should assume the nature of research;

- with the material for independent study, the modern student is more motivated to perform creative research tasks, like preparation of papers, abstracts, research of school experience, presentation at student scientific conferences, preparation for colloquiums, writing of coursework, graduation works to further studying the problematic topics of lectures.

Such individual and practical activity will be more pedagogically effective for the professional competence formation of a future specialist. Moroz also emphasized the importance of systematic and continuous nature of individual student work, which can be ensured not by increasing time for work but by its more rational distribution between subjects, according to the semester schedule, taking into account the significance of their specifics.

Keywords: individual work, educational out-of-class work, effective pedagogical conditions, practical students' training.

Formulation of the problem. New challenges faced by third level educational institutions require search for ways to improve their educational process. The transition to the implementation of the new paradigm of higher education means the renewal of all its parties: the content, forms of organization, methods and means of learning.

In recent time, the educational process in Ukrainian higher education institutions has become more complex in its tasks, more intense than its content. It requires a profound pedagogical rethinking of educational and professional processes, the principles and methods of teaching, education and formation of the personality of a future specialist. This is provided by significant changes in the system of higher education in Ukraine [2, P.6].

Research goal is to analyze the place and role of individual student work and determine the effective conditions for its provision as part of their practical training in the research of O. H. Moroz.

Objectives:

- analyze the subject of individual students' work in scientific literature;

- to study the components and their characteristics of out-of-class academic work in O. H. Moroz' studies;

- To substantiate the factors influencing the organization and implementation of individual educational students' work in third level educational institutions in Oleksiy's Hrygorovych Moroz scientific and pedagogical works.

Analysis of recent research and publications. O. H. Moroz developed system of future teacher's psychological and pedagogical preparation, for example, humanization and humanitarization of the content of pedagogical education, improvement of individual educational students' work, formation future teachers' pedagogical creativity and professional skills, improvement of retraining of pedagogical staff quality etc. [8].

Ideas of students' autonomic activities were supportedbe famous surgeon and teacher M. I. Pyrogov, who came to the conclusion that classroom classes can be effective only after individual students' work. He made an exception for lectures from unpublished materials and for prominent lecturers. M. G. Chernyshevskyi also supported this thought. D.I. Pisareva believed that "true education is only self-education" [1, P. 35].

Study presentation. Moroz Oleksiy Hrygorovych (19402007 ) is Ukrainian teacher, public and political activist, academician of the Academy of Pedagogical Sciences of Ukraine, author of approx. 200 scientific works.
Scientific and pedagogical activity O. H. Moroz includes: teaching at the Rossochovtsy secondary school in Katerinopolsky district of Cherkasy region (1959-1960) and Yurkiv high school of Zvenigorod district of Cherkasy region (19601962); work as assistant at Gorky University (1968) in Department of Physics Teaching Methodology; Postgraduate student degree of the Department of Pedagogics at Taras Shevchenko National University of Kyiv (1968-1971); work as assistant, researcher, senior teacher of the laboratory of scientific basis of higher pedagogical education at Gorky University (1971-1974). He defended his Ph.D. thesis "Ways of ensuring continuity in individual study of students of secondary schools and students of higher educational institutions" (1972) and therefore became an Associate Professor of the Department of General Pedagogics Gorky University (1975) and than Deputy Dean of the Faculty of Physics and Mathematics at Gorky University (1974-1975); Acting Associate Professor, Department of Pedagogy, Gorky University (1975); Senior Researcher (Doctorate) of the Department of Pedagogy, Gorky University (1976-1978); Head of the Laboratory of Higher Pedagogical Education, Gorky University (1978-1981); Head of the Department of Scientific Foundations of the Department of Comprehensive School of Gorky University (1981-1986); defended his doctoral dissertation "Professional adaptation of a graduate of a pedagogical higher educational establishment" (1984); Professor of the Department of Scientific Foundations of the Department of General School of Gorky University(1985); Dean of the Pedagogical Faculty of Gorky University. In 1992-1995 he was a Minister of Education of Ukraine (19861991), a full member of the National Academy of Pedagogical Sciences of Ukraine (1992); vice-chancellor of the Institute of Postgraduate Education of Kyiv National Taras Shevchenko University (1995-1997); Professor of the Department of Theory and History of Pedagogy of the Ukrainian National Pedagogical University named after Drahomanov (1997-1999); Head of the Department of Pedagogy and Psychology of the Higher School of the National Pedagogical University named after Drahomanov (2000-2007).

O. H. Moroz's is honored for The Excellence in Public Education of the USSR (1983), the Excellence in Education of Ukraine (2004), was awarded with medals: "1500th Anniversary of Kyiv", "Veteran of Labor", "Medal of A. S. Makarenko", Order of "Saints Cyril and Methodius", 
Diploma of Honor Verkhovna Rada of Ukraine, numerous certificates of the Ministry of Education and Science of Ukraine. He is the author of approx. 200 scientific works. Under the guidance of Academician O. H. Moroz 19 doctoral and 77 candidate's theses have been protected. For many years he has been the chairman and a member of the specialized councils for the defense of candidate and doctoral dissertations on pedagogy and psychology at the Drahomanov NPU.

Since 2010 at the National Pedagogical University named after. M.P. Dragomanov under the auspices of the Ministry of Education and Science of Ukraine and the National Academy of Pedagogical Sciences of Ukraine Morozov pedagogical readings are being held. These events are dedicated to the memory of the famous Ukrainian scientist, teacher, doctor of pedagogical sciences, professor and academician of the National Academy of Sciences of Ukraine Olexiy Morozov. Thematic meetings of Morozov's readings are held every two years [5].

In modern society, where the volume of information is constantly increasing, third level educational institutions prioritise individual students' work in quantitative and qualitative dimensions by reducing the auditorium time. In the framework of the systematic approach to the organization and implementation of the educational process in third level educational institutions it is provided ways to establish a link between the content, means and forms of learning, as well as between the educational and extracurricular activities of students at all stages of their pedagogical education [3].

Investigating the organization of individual work, O.M. Moroz determines that it is a form of training in which the student acquires the necessary knowledge, acquires skills and abilities, learns systematically, systematically work, think, forms his own style of mental activity. Its distinction from other forms of learning is because it involves the ability of the student to organize himself according to the tasks [4, P.48].

O.M. Moroz highlights such factors of effectiveness of individual students' work [6]:

- any work includes an element of individual work in the sense that a person learns a learning material always by him/herself;

- the actual work involves the greatest variety of forms of activity of those who study, therefore, provides the highest level of consuming;

- only an individual work, processing of the material gives knowledge and belief;

- individual work is the basis for the future self-education of a specialist, it forms the corresponding motivation and skills of self-education.

But preparation of students for individual work and management has a number of problems, which includes such components as motivational, technological and organizational. The first component is about creating high motivation focused emphasis on the teacher's special significance of individual work among all other forms of learning. One of the meanings here should be giving sufficient time for individual work, which is planned as part of the educational process. The organizational component is closely linked to the motivational one. It is about proposing the reasonable time rates for these or other forms of educational work to students, as well as planning their homework taking into account these norms. In addition to reasonable time standards, psycho-hygienic and psychoprophylaxis standarts are important to organize students [4, P. 48].

Technological component has no less value for individual work. The low level of student abilities prevents them from mastering even a fairly simple material. Therefore, the organizer of individual students' work faces the following tasks: it is grounded to determine the correct amount of educational material, which is carried out for individual work and processing of the motivational and technological aspect of students' preparation for it.

Understanding the skills and abilities of students' individual work includes:

- ability to prepare for a certain type of activity (for example, a lecture or seminar session), participation in activities (for example, work at a seminar);

- general ability to perform educational work (for example, ability to make statements or make extracts);

- ability to plan their time, to carry out the agenda, the hygiene of mental work and psychohygiene.

Within the framework of his research, Oleksiy Hrygorovych offers to use classification types of individual students' work by P.I. Podkisisty. He divides individual work to samples (solving typical tasks, performing various exercises according to the sample); reconstructive-variational (implying the need to reproduce not only the functional characteristics of knowledge, but also the structure of knowledge, the use of known knowledge for solving problems, problems, situations); heuristic (partially exploratory); creativity and research (related to the solution of certain issues, problems posed at lectures, seminars, laboratories, practical classes); individual research work (which implements the student's creative abilities) [7].

Educational abilities and skills for successful individual work include skills and abilities to work with pedagogical literature, that is a professional-oriented reading [4, P. 51].

To be specific, these are skills of intellectual-logical reading development, which include the following characteristics:

- orientation towards the perception and assimilation of the experience of previous generations, those knowledge that humanity has already accumulated in the field of pedagogical activity;

- reading as a special form of speech communication of people, which is carried out with the help of printed texts, involves a certain exchange of information, knowledge, results of work;

- understanding it not only as an active form of verbal written communication, but also as a reading-dialogue, reading-conversation, perhaps as a controversy between the reader and the author;

- such reading is usually aimed at the further use of the useful information received either directly or in the form elaborated by the author;

- the direct reading of pedagogical literature, in a certain way, influences the decision of specific tasks of educational work, forms personal views, positions, instructions for the future pedagogical activity;

- ability to revive knowledge collected in print sources, turn them into an informational basis for pedagogical activities of a student and a teacher;

- it involves the obligatory presence of the reader in the established plan of hope, the hypotheses with which he begins to read any text;

- in the process of reading there is a meaningful interaction between the two participants in communication: one tries to influence another in accordance with personal views and ideas about the object being described;

- subordination: in a dynamic hierarchical structure of the activities of a teacher or a student, it never acts as a leading activity, but always subordinate to knowledge, creativity, self-education. It has an indirect effect on the effectiveness of teaching and teaching work; 
- professional-oriented reading is always aimed at a large number of primary sources and involves the number of texts that the reader acquaints with;

- the reader, according to his own desires and inclinations, can repeatedly use one or another literature [4, P. 53].

Hence, professional-oriented reading is a complex intellectual activity due to the professional information needs of the reader, which is a form of active indirect, verbal written communication-dialogue and the main purpose, which is the perception, assimilation and subsequent purposeful use of the experience accumulated by mankind, the country in the field of pedagogical knowledge, which promote long professional self-education, self-development and self-improvement.

To ensure effective individual students' work, O. H. Moroz emphasizes on the following terms of its organization:

- Planning for each discipline. This includes all types of individual work, its volume, as well as the terms of implementation at the organizational leadership of the dean's offices and departments. For successful planning of individual work, the following requirements should be observed: at the beginning of the semester it is necessary to make a plangrid of disciplines studied in this semester, and to indicate from each discipline (in months or even days) the execution of certain tasks that are necessary for assimilation content of the subject; it is necessary to systematically work with the completed plan: mark the performance, results, assessments, if there are any. At the same time, be sure to mark a specific date or at least a week of its beginning and ending. Comparison of the time allocated for a specific task with the obtained assessment and result enables to evaluate the effectiveness of the organization of individual work: from which subjects and for which tasks should be increased or reduced time spent on work. This will help one to select the optimal timetable for learning the tasks;

- a combination of individual work with other forms of learning. For example, a lecture using problem-searching methods of teaching, a priori, involves individual students' work;

Within the limits of individual students' work under teacher's guidance there are colloquiums (which allow to find out the degree of understanding of the content of listened lectures and determine how students work on the recommended literature) or interviews (when students explain how to work on the material of the lecture and recommended manuals).

In addition, Moroz Oleksiy Grigorievich believes that consultations are important in the organization of individual students' work. Consultation can act as the main form of the educational process and additional. Appointment of counseling is assisting in the individual students' work and teaching them to learn [4, P. 45]. In addition, the level of training of students, especially the freshmen, is not quite the same. Therefore, for their more effective learning and other students' training, there is a need to use such forms of education as counseling.

Consultations can help to keep track of the process of students' perfomance, their compliance with their curricu- lum. And they will help the students themselves to understand their abilities and influence the formation of individual work skills, when performing individual tasks, to perform more complex tasks, to understand the nature of these tasks better and so on. Well-organized and conducted counseling is one of the methods of purpose-directed leadership of individual student learning activities. The teacher who advises not only answers the instructed questions for students, but also seeks to understand their thoughts, to identify the peculiarities about their consuming of the material, aspire to recognize and support interesting thoughts, and give advice on a better understanding of the educational material [4, P. 45]. Short interviews at the beginning of the classroom can also help students in their own work, when students explain how to work on the materials of these classes and recommended literature [2, P. 103].

Conclusions. Consequently, individual study students' work will be effective if it is provided by their objective selfesteem in unity with the development of skills for individual cognitive activity. It should not be an aim itself, but serve as an active means for understanding educational information by students, their application of the acquired knowledge and skills in practice $[4$, P.79]

References

1. Educational process in higher pedagogical school: Teaching. manual / per community Ed. O. G. Moroz. - K. : NPU them. M.P. Dragomanov, 2001. - 337 pp.

2. Moroz O.G., Padalka O.S., Yurchenko V.I. Pedagogy and Psychology of Higher School: Textbook / For Collegiate. Ed. O.G. Frost - K. : NPU, 2003. $-267 p$

3. Moroz O. The Personality of the Future Teacher (Teacher's Training Management: Psychological-Pedagogical Aspect) // Higher Education of Ukraine. -2008

4. Moroz O.P., Padalka O. S., Yurchenko V.I. Teacher of higher school: psychological and pedagogical bases of preparation of Teach. manual / per community Ed. O. G. Moroz - K. : NPA, 2006. - 206 p.

5. Pedagogy and Psychology of Higher School: Bibliography / Uk. O. G. Moroz, V. I. Yurchenko - K.: NPU them. MP Drahomanov, 2001. - $38 \mathrm{p}$.

6. Independent educational work of students: Method, recommendations / O.G. Moroz (for an issue), O.D. Chekurd, G.O. Chekurd, D.S. Ryaschenko K., KDsh, 1987. - 72 p.

7. https://www.cuspu.edu.ua/download/conf2013/section2/article voitovich.pdf

8. https://uk.wikipedia.org

Список використаних джерел

1. Навчальний процес у вищій педагогічній школі : навч. посіб. / за заг. ред. О. Г. Мороза. - К. : НПУ ім. М. П. Драгоманова, 2001. - 337 с.

2. Мороз О. Г. Педагогіка і психологія вищої школи : навч. посіб. / О.Г. Мороз, О.С. Падалка, В.І. Юрченко ; за заг. ред. О.Г. Мороза. - К. : НПУ, 2003. - 267 с

3. Мороз О. Особистість майбутнього педагога (Управління підготовкою вчителя: психолого-педагогічний аспект) / О. Мороз // Вища освіта України, 2008.

4. Мороз О. П. Викладач вищої школи: психоло-го-педагогічні основи підготовки : навч посіб. / О.Г. Мороз, О.С. Падалка, В.І. Юрченко ; за заг. ред. О.Г. Мороза. - К. : НПУ, 2006. - 206 с

5. Педагогіка і психологія вищої школи : бібліографрія / укл. О.Г. Мороз, В. І. Юрченко. - К. : НПУ ім. М. П. Драгоманова, 2001. - 38 с.

6. Самостійна навчальна робота студентів : метод. рекомендації / О. Г. Мороз (відп. за вип.), О. Д. Чекурда, Г. О. Чекурда, Д.С. Рященко. К. : КДШ, 1987. - 72 c.

7. URL: https://www.cuspu.edu.ua/download/conf2013/section2/article voitovich.pdf https://uk.wikipedia.org

Надійшла до редколегії 05.03.19

О. Поляк, канд.пед. наук, доц.

Київський національний університет імені Тараса Шевченка, Київ, Україна

\section{ОСОБЛИВОСТІ ПРАКТИЧНОЇ ПІДГОТОВКИ СТУДЕНТІВ У НАУКОВО-ПЕДАГОГІЧНИХ ДОСЛІДЖЕННЯХ ОЛЕКСІЯ ГРИГОРОВИЧА МОРОЗА}

Досліджено науково-педагогічну спадщину Мороза Олексія Григоровича, порушено питання важливості позааудиторної роботи сучасних студентів, розкрито поняття та зміст їхньої самостійної роботи, визначено педагогічні умови забезпечення самостійної навчальної діяльності слухачів закладів вищої освіти. Проаналізовано науково-педагогічну спадщину О.Г. Мороза, закцентовано на важливості ефективної організації та педагогічних умовах забезпечення самостійної навчальної роботи студентів. Визначено, що в умовах активізації творчої пізнавальної діяльності студентів у навчальному процесі, самостійну роботу не можна зводити до виконання лише нормативних домашніх завдань. Розпочинатись самостійність і творча активність студентів має не в аудиторії при слуханні та сприйманні лекції, а при підготовці до них у лабораторії, бібліотеці, під час практики в школі і т. ін. Ця діяльність, з 
переходом студентів на старші курси, все більше має набувати, за словами О.Г. Мороза, характеру дослідницького пошуку. 3 матеріалом, який виноситься на самостійне вивчення, для більшого поглиблення проблемних тем лекцій сучасний студент більш мотивований виконувати творчі науково-дослідні завдання: підготовка доповідей, рефератів, дослідження шкільного досвіду, виступ на студентських наукових конференціях, підготовка до колоквіумів, написання курсових, дипломних робіт. Така їхня практична діяльність буде більш педагогічно ефективною для формування професійної компетентності майбутнього фахівця. Також важливими в організації самостійної роботи студентів науковець вважає проведення консультацій, які можуть бути як основною формою навчального процесу, так $i$ додатковою. Призначення консультації- надання допомоги в самостійній роботі студентів та навчати їх учитись. Окрім того, самостійна навчальна робота студентів має бути організованою, за умови формування у них об'єктивної самооцінки в єдності з виробленням навичок самостійної пізнавальної діяльності. Вона має слугувати активним засобом для осмислення студентом навчальної інформації, застосування одержаних знань, умінь на практиці. О. Мороз наголосив також на важливому значенні системного та постійного характеру самостійної навчальної роботи студентів, що може бути забезпечено не на збільшенні часу, а на більш раціональному розподілі його між предметами відповідно до семестрового графіка з урахуванням значення їхньої специфіки.

Ключові слова: самостійна робота, навчальна позааудиторна робота, ефективні педагогічні умови, практична підготовка студентів.

UDC 371

N. Postoiuk, Ph. D. (Pedagogical of Sci.)

Taras Shevchenko National University of Kyiv, Kyiv, Ukraine

\section{PECULIARITIES OF PRACTICAL TRAINING OF BIOLOGY TEACHERS IN D. SERGIENKO'S PEDAGOGICAL HERITAGE}

D. Sergienko's ideas concerning the practical training of biology teachers have been analyzed. The main objectives and requirements to the teacher of biology at school have been highlighted. The peculiarities of organization of observation, experiment, laboratory and practical works have been revealed. The conditions of formation of students' abilities and skills of research character, as well as factors, which promote the development of interest in research work, have been determined. This scientific research has revealed that $D$. Sergienko considered the practical training of biology teachers as a very important thing because effective teaching of biology could help to improve the state of agriculture in the country, also this educational subject cultivates love for nature, expands knowledge about plant and animal life, promotes the choice of profession in the agro-industrial sector. D. Sergienko was sure that the biology teachers have a huge responsibility, because they have to raise the awareness of children in creative work in rural society. This goal can be realized if you have such personal qualities as the teacher's love for this subject, pedagogical skills, the ability to supervise and teach the children, the ability to work with the public and, especially, with children's parents.

Keywords: practical training, D. Sergienko, observation, research, biology teacher.

Formulation of the problem. The problem of practical training of teachers is very actual today, because it is one of the most important stages in the formation of a professional. If a student is prepared for future activities qualitatively, then he will be able to apply the obtained theoretical knowledge in practice, will receive the necessary knowledge and skills, will be competitive at the modern labor market. The reform of education in Ukraine is aimed at improving the practical training of students, the formation of general, integral and subject competencies. Program learning outcomes include knowledge and understanding of the subject area and professional activity, the ability to apply knowledge in practical situations and teamwork, ability to identify, solve problems. In accordance with the new requirements teachers must describe the expected learning outcomes in detail, forms, methods and teaching techniques, as well as assessment methods for the writing new programs for disciplines. In this case, the experience of domestic educators, who offered different ways to improve the training of future teachers may be useful. In particular, D. Sergienko's methodological recommendations concerning the organization of the work of biology teachers in secondary schools are worth attention.

Analysis of recent research and publications. The practical training of biology teachers has become the topic of research for many Ukrainian scientists. Problems of methodical preparation of teachers of natural sciences disciplines were studied by T. Gusakovsky, Yu. Shapran, L. Nikitchenko, N. Levchuk, I. Moroz and others. The questions of the peculiarities of the methodology of teaching biology were studied by M. Versilin, V. Kuznetsov, M. Matveev, V. Kolodiy, V. Sobol, D. Stepanyuk, O. Honchar, L. Rybalko, I. Sudakova and others. In particular, L. Nikitchenko, N. Levchuk are sure that "teachers of natural sciences must be able to establish the relationship between theory and practice when studying the course of biology at school, scientifically competently and didactically feasible to organize educational work about subjects of the natural cycle at the educational-research land site, during excursions, in out-of-school establishments. The students' knowledge obtained during professional practice contributes to the rational conduct of teaching and research work at the lessons, mastering the methods of its implementation, organizing naturalistic and environmental work in the school" [1, p. 4].

Research goal and objectives. The goal of the article is to analyze D. Sergienko's ideas concerning the practical training of biology teachers. To achieve the goal, the following objectives were set: 1) to highlight the main tasks of biology teachers in school and the requirements to them; 2) to reveal the peculiarities of the organization of observations, researches, laboratory and practical work; 4) to determine the conditions for the formation of students' abilities and skills of research character, as well as factors that contribute to the development of interest in research work.

Study presentation. D. Sergienko supposed that during the preparation of biology teachers the methodology of teaching should be based on the didactic principle with combining theory with practice in the process of work with the program. He offered through the improvement of biology teaching successfully to accomplish the following objectives: to develop cognitive interest in the surrounding world, to develop the ability to apply theoretical knowledge in practice, to form children's love for nature and creative approach to work. The scientist emphasized that it is very important to construct all educational work at the lessons so that children perceive plants and animals as living beings in their unity with the conditions of existence. He believed that "only the feeling of alive being and knowledge of the physiological needs of this organism can provide an attempt to create the best conditions for their development, a careful attitude to plants and animals, which causes a desire to learn more deeply about their physiological needs, the means to satisfy these needs, and the pupils start to listen to an explanation 